\title{
Detección del movimiento cíclico estacional en edificios históricos por métodos topográficos
}

\section{Detection of the seasonal cyclic movement in historic buildings by means of surveying techniques}

\author{
J. M. Valle-Melón ${ }^{(*)}$, Á. Rodríguez-Miranda(*), P. Pérez-Vidiella(*)
}

Recepción/Received: 3-IX-09

Aceptación/Accepted: 21-I-10

Publicado online/Online publishing: 4-III-11

\section{RESUMEN}

Al igual que el resto de estructuras de ingeniería, los edificios históricos están sometidos a las variaciones de las condiciones atmosféricas que afectan a sus dimensiones. Estos efectos son de carácter cíclico y no suelen suponer riesgo para la estabilidad del edificio, ya que se encuentran dentro de su dinámica natural, sin embargo, su determinación aporta información valiosa a la hora de entender el comportamiento tanto del edificio como de los materiales que lo conforman.

Los resultados que se presentan surgen del proyecto de auscultación geométrica de un edificio histórico supuestamente inestable, la Iglesia de Santa María la Blanca de Agoncillo (La Rioja, España), que se viene realizando utilizando instrumentación topográfica convencional. En el cálculo de las diferentes campañas se han podido detectar movimientos cíclicos estacionales

Palabras clave: movimientos cíclicos, auscultación, topografía, patrimonio.

\section{SUMMARY}

As in other engineering structures, historic buildings are conditioned by atmospheric changes which affect their size and shape. These effects follow a more or less cyclic pattern and do not normally put the stability of such buildings in jeopardy since they are part of their natural dynamics. Nevertheless, the study of these effects provides valuable information to understand the behavior of both the building and the materials it is made of.

This paper arose from the project of geometric monitoring of a presumably unstable historic building: the church of Santa María la Blanca in Agoncillo (La Rioja, Spain), which is being observed with conventional surveying equipment. The computations of the different epochs show several movements that can be explained as due to seasonal cycles.

Keywords: cyclic movements, monitoring, surveying, heritage.

(*) Universidad del País Vasco (Álava, España). 


\section{INTRODUCCIÓN}

El control geométrico de los edificios y estructuras, conocido generalmente como auscultación, aporta información que puede ser interpretada en función del comportamiento de los materiales o la presencia de situaciones de inestabilidad.

Existe una amplia variedad de dispositivos y técnicas que proporcionan información a este respecto: extensómetros, medidores de convergencia, fisurómetros, inclinómetros, etc. Entre ellas, las técnicas topográfico-geodésicas (que incluyen las medidas con teodolitos, estaciones totales, escáneres láser tridimensionales, GPS o cámaras fotogramétricas) se caracterizan por determinar la posición de una serie de dianas que se utilizan como puntos de control. La comparación entre las coordenadas calculadas en diferentes campañas informa sobre los desplazamientos producidos.

En realidad, los desplazamientos en sí no suelen ser las magnitudes relevantes para los estudios sobre el edificio, sino que se suelen transformar con el fin de poder interpretarlos; por ejemplo, en el caso de una estructura inestable que esté sufriendo un asentamiento progresivo, puede ser interesante convertirlos en velocidades (dividiendo el desplazamiento entre el tiempo transcurrido), mientras que si lo que se busca es analizar el comportamiento de los materiales frente a las variaciones atmosféricas se pueden intentar relacionar con los valores de temperatura y humedad de cada campaña. Sin embargo, esta conversión no es directa; entre otros motivos, hay que tener en cuenta:

- Las medidas estarán afectadas de ruido y su precisión vendrá limitada por el instrumental y la pericia de los observadores (en el caso de no utilizar equipamiento que realice las medidas automáticamente), lo que significa que los valores obtenidos deben considerarse dentro de un margen de indeterminación. Esto es válido para cualquier tipo de medida, pero resulta crítico en estos casos en los que las magnitudes de los desplazamientos (señal) son tan pequeñas que pueden confundirse con el ruido.

- La naturaleza discreta de las medidas: se realizan campañas en momentos puntuales separados temporalmente, pero se trata de registrar el resultado de un proceso que se ha ido produciendo de forma continua a lo largo del tiempo.

- Los desplazamientos son debidos a varias causas que actúan de forma simultánea.

Por lo tanto, antes de aceptar los valores calculados a partir de los desplazamientos hay que asegurar que éstos son realmente significativos. De hecho, el análisis de los márgenes de incertidumbre y significación es tan importante como la propia determinación de las coordenadas.

\section{INTRODUCTION}

Monitoring is the name usually given to the geometric control of buildings and structures. It provides information that can be interpreted according to the behavior of the materials or the existence of states of instability.

There is a wide range of devices and techniques providing geometrical data such as extensometers, wires to measure the convergence, crack meters, tilt sensors, etc. Among them, surveying and geodetic techniques (which cover measurements taken with theodolites, total stations, terrestrial laser scanners, GPS or photogrammetric cameras) are characterized as determining the position of a series of targets used as control points. Displacements are reported by the comparison between the coordinates of these targets at successive epochs.

Actually, for most studies, displacements by themselves are not meaningful values, so they are often transformed in order to interpret them. For instance, given an unstable structure undergoing progressive settlement, it can be useful to transform displacements into velocities (by dividing the magnitude of the displacement by the timespan), whereas if we aim at analyzing how atmospheric changes affect materials, it may be possible to relate them to temperature and humidity. However, this conversion is not straightforward for reasons that include the following:

- The accuracy of the measurement will be limited by noise and equipment, as well as the observer's skill (unless data are collected automatically). Therefore, the values obtained have to be considered inside an indetermination range. That is valid in general but especially critical when the displacements (signal) are so small that they can be mistaken for noise.

- $\quad$ The nature of the measurements is discrete (epochs are observed in moments distributed along time) but we try to register the result of a continuous process.

- Displacements are the result of several causes applying simultaneously.

Consequently, before accepting the computed displacements it must be ascertained that they are truly meaningful. In fact, significance analysis and the assessment of the uncertainty are as important as the coordinates themselves. In the third section of this paper 
En el tercer apartado de este artículo se repasarán estos conceptos con los resultados de la auscultación que se está llevando a cabo en la iglesia de Agoncillo, pero antes vamos a centrar brevemente el propio proyecto de control geométrico del edificio.

\section{PROYECTO DE AUSCULTACIÓN DE LA IGLESIA DE SANTA MARÍA LA BLANCA}

Para comprender el proyecto que se está llevando a cabo en la Iglesia de Santa María de la Blanca en Agoncillo (La Rioja) es necesario plantear la problemática general de la gestión del patrimonio, que afecta a las diferentes administraciones encargadas de su conservación y que está relacionada con la gran cantidad de edificios a mantener y el escaso presupuesto disponible. En este contexto, la auscultación se entiende como un estudio que permite aportar conocimiento con el fin de optimizar los recursos, ayudando a determinar qué elementos patrimoniales requieren intervenciones más urgentemente y en qué zonas. Hay que resaltar que la auscultación geométrica detecta los movimientos como efecto del estado del edificio, no determina las causas que los generan pero sí indica dónde deben buscarse.

El problema de este planteamiento es que las propias auscultaciones son costosas, por lo que, en la realidad, sólo se plantean en los monumentos más relevantes o aquellos situados en centros urbanos cuya visibilidad y reconocimiento público favorecen su mantenimiento. Por el contrario, la mayor parte del patrimonio -entre el que cabe citar monasterios, ermitas, castillos o puentes y que se encuentra disperso en pequeñas localidades- queda excluido de este tipo de estudios. Por este motivo, existe un especial interés en desarrollar metodologías de bajo coste que permitan aumentar la nómina de edificios controlados; en esta línea se enmarca el uso de instrumentación convencional tanto en la señalización de los puntos de control sobre el edificio como el equipo topográfico utilizado (para este proyecto se ha utilizado una estación total Leica TCR 1205) en la adquisición de datos.

La descripción detallada de la metodología de observación no es objeto de este texto y ya fue tratada en una ocasión anterior (1). De forma breve se puede decir que, además de varias grietas de considerable magnitud, la iglesia cuenta con una torre anexa que presenta una notable inclinación (cercana a los 2 grados sexagesimales, con una separación de $40 \mathrm{~cm}$ a la altura del tejado de la nave, situada a $17 \mathrm{~m}$ de altura).

Para el control, se situaron 53 señales de puntería distribuidas por la torre, fachadas exteriores de la iglesia y edificios cercanos. El cálculo de las coordenadas se realiza mediante intersección angular utilizando el sistema de we will review these concepts with reference to the results of Agoncillo, but, for the time being, we focus on the monitoring project itself.

\section{MONITORING PROJECT OF SANTA MARÍA LA BLANCA CHURCH}

It is necessary to start this section by describing the situation affecting the management of the heritage in order to better understand the project that it is being carried out in the church of Santa María la Blanca in Angoncillo (La Rioja). The authorities in charge of the maintenance of the heritage have indeed a long catalog of buildings to upkeep and a limited budget at their disposal. In this context, monitoring is seen as a way to optimize the available resources by providing information about each element, which allows determining which ones need acting more urgently and where. In this respect, it must be emphasized that, although monitoring can detect movements it is unable to determine why they happen. Nonetheless, these studies can help to locate where the reasons have to be sought.

Unfortunately, this approach is less helpful than it seems to be because the monitoring itself tends to be expensive. Indeed, monitoring is only considered for the most relevant buildings or those that are placed in historical centers and, as such, are visible and acknowledged by society. On the contrary, most of the heritage - with includes monasteries, hermitages, castles, bridges, etc. - is scattered all over in rural and sparsely populated areas. These elements have little access to monitoring projects and thus the interest in developing low-cost methodologies that can increase the number of controlled buildings. The use of conventional surveying equipment (in this project we have used a Leica TCR 1205) and common targets conforms with this aim.

The detailed description of the methodology of observations is outside the scope of this paper and has been described elsewhere (1). Briefly it can be said that, apart from several cracks of considerable size, the church counts on an annexed tower presenting a noticeable leaning (around 2 sexagesimal degrees, with a detachment of 40 centimeters at the height of the roof of the nave located to 17 meters high).

For the follow-up, 53 targets where embedded all over the tower, façades and surrounding buildings. They were observed from several locations. Two points (C31 and $\mathrm{C35}$ ) define the reference system and the 


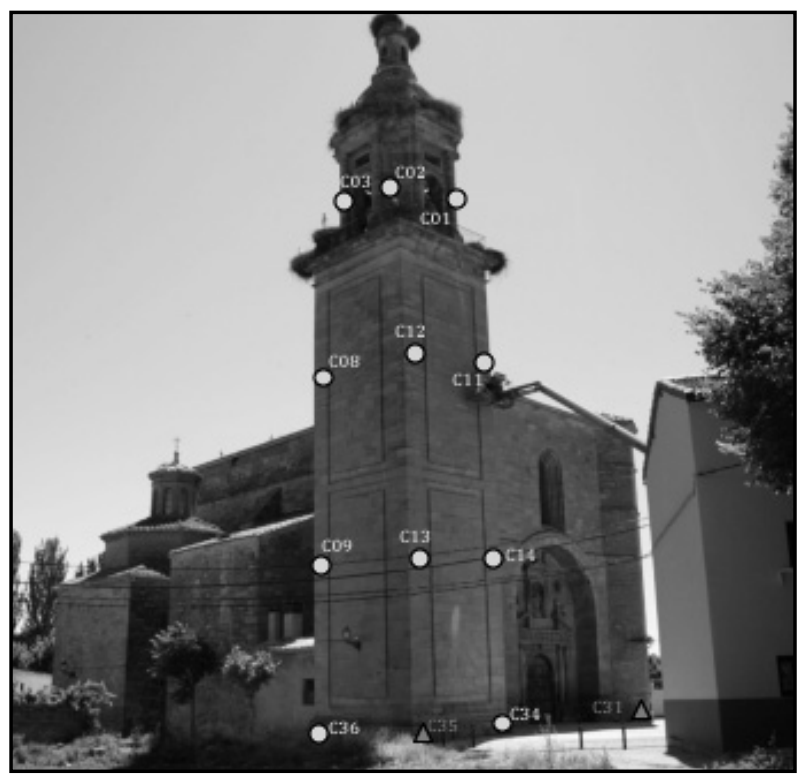

Figura 1. Localización de las señales de la torre. Las señales C31 y C35 definen el sistema de referencia. Figure 1. Placement of the targets on the tower. Points C31 and C35 define the reference system.

referencia definido por las señales C31 y C35. En la Figura 1 se presenta una fotografía en la que aparecen marcadas estas señales de referencia y las dianas situadas en la torre que son en las que centraremos este texto.

Se dispone de campañas de observación realizadas cada tres meses desde julio de 2007 (octubre de 2007, enero de 2008, abril de 2008, julio de 2008, octubre de 2008, enero de 2009, abril de 2009 y julio de 2009). En lo sucesivo, sólo se tendrán en cuenta las correspondientes a los meses de julio y enero, ya que corresponden a los momentos extremos del ciclo anual y son entre los que se ha detectado este movimiento.

\section{REPRESENTACIÓN DEL CICLO ESTACIONAL}

La utilización de medidas topográficas para el control de movimientos está plenamente establecida, siendo quizás su referencia básica el texto (2) y cuyas descripciones más completas en español pueden encontrarse en (3) y (4).

El cálculo de cada campaña se realiza incluyendo todas las observaciones realizadas en campo y tiene tres fases principales:

1. Cálculo de las coordenadas de las dianas mediante ajuste por mínimos cuadrados.

2. Estimación de las incertidumbres asociadas a los valores calculados.

3. Control estadístico del proceso de ajuste. coordinates are computed by triangulation using only angles. The following photograph (Figure 1) shows the position of some of these targets and, specifically, the ones corresponding to the tower, on which we will focus in the remainder of this paper.

The observations have been collected every three months from July 2007 (October 2007, January 2008, April 2008, July 2008, October 2008, January 2009, April 2009 and July 2009). From now on, we will take into account only the ones collected in July and January since they represent the extreme positions of the seasonal cycle (winter-summer) and where the movements have been detected.

\section{REPRESENTATION OF THE SEASONAL CYCLE}

The methodology and use of surveying measurements to monitor structures is well established. The basic reference is (2) and the most complete descriptions in Spanish could be (3) and (4).

The computation of each epoch is done with all the angular observations that have been taken and consists of three main stages:

1. Computation of the coordinates of the targets by least squares adjustment.

2. Estimation of the uncertainty attached to each computed value.

3. Statistical checking of the adjustment process. 
De estos tres pasos, el tercero es el más desconocido, aunque también es ineludible, ya que permite garantizar que los valores que se presentan son coherentes con las medidas proporcionadas. Hay que tener en cuenta que este tipo de ajustes matemáticos son fácilmente contaminables por medidas incorrectas, sistematismos instrumentales, etc., y que además los errores no imposibilitan la obtención de resultados que, a primera vista, pueden parecer correctos.

La representación de los resultados es una elipse centrada en las coordenadas calculadas, la orientación y dimensiones de la misma dependen de la geometría de las observaciones y su precisión, marcando un área de confianza con una probabilidad estadística del $99 \%$. Se trata de elipses porque lo que se estudia en este caso es la posición en el plano XY (si fuese un estudio en XYZ se trataría de elipsoides). Para el proyecto de Agoncillo, se decidió estudiar el fenómeno en dos dimensiones en lugar de tres porque simplificaba en gran medida todo el proceso (observación, cálculo e interpretación) y no implicaba renunciar al análisis tridimensional del edificio, ya que puede inferirse, al menos parcialmente, a partir del comportamiento bidimensional de señales situadas a diferente altura en la misma vertical. Los valores de los semiejes mayores para estas elipses son de unos $3 \mathrm{~mm}$.

Para analizar el comportamiento de un punto en dos campañas diferentes, se dibujan las elipses correspondientes y se comprueba si éstas aparecen separadas (en cuyo caso, se habrá producido un desplazamiento significativo) o si se intersecan (lo que indicará que la indeterminación de las coordenadas es mayor que la diferencia detectada). La significación de los desplazamientos también se puede estudiar de forma numérica mediante test estadísticos que tienen en cuenta la información de las matrices de varianza-covarianza de cada ajuste, sin embargo, la representación gráfica proporciona una información más global y fácil de interpretar.

En la Figura 2 se presentan las elipses, en color gris claro, correspondientes a las señales de la torre en las tres campañas de julio (2007, 2008 y 2009; no se identifica cuál representa a cada campaña porque no se considera relevante en este gráfico). Como puede apreciarse, en todos los casos las elipses intersecan, lo que permite concluir que, dentro de la indeterminación de las coordenadas calculadas (unos $3 \mathrm{~mm}$ ) no existen diferencias entre las posiciones de cada campaña.

En vista de esta coincidencia en la posición de todas las épocas, se puede plantear realizar un cálculo conjunto que denominaremos "estado promedio de julio" que incluye las medidas de las tres campañas de forma simultánea. El resultado está representado por el aspa (coordenadas calculadas) y la elipse de línea gruesa en
The aim of the third stage is to ensure that the results are coherent with the measurement. This is probably the most unknown of the three stages but turns out unavoidable. We must be careful with this kind of mathematical adjustments since they are easily contaminated by mistakes and systematic error in the equipment. Moreover, errors do not block the attainment of results which, can seem correct to the naked eye.

The results are represented by means of an ellipse centered at the calculated coordinates. Orientation and size depend on the geometry of the observations and their accuracy and they define an area of confidence with a probability of $99 \%$. They are ellipses since what we are studying in this case is the position on the $X Y$ plane (if it was a study in XYZ they would be ellipsoids). For the case study of Agoncillo we decided to survey the movements two-dimensionally instead of three-dimensionally because this consideration simplifies, to a large extent, all the process (observation, computation and interpretation) and does not imply to give up the three-dimensional analysis of the building because it can be inferred, at least partially, from the two-dimensional behavior of the targets located at different height in the same vertical line. The values of the major semi-axes are about $3 \mathrm{~mm}$.

The analysis of the behavior of one point between two epochs is done by drawing the corresponding ellipses and verifying whether they appear separated (in which case, there has been a meaningful displacement) or if they intersect each other (which will indicate that the uncertainty of the coordinates is bigger than the detected difference). The significance of the displacements can be also studied in a numeric way through statistical testing, which takes into account the information in the variancecovariance matrixes of each adjustment. The graphic representation, however, gives overall information and is easier to interpret.

The Figure 2 presents, in light grey, the ellipses corresponding to the targets on the tower for the three July's epoch (2007, 2008 and 2009; they are not individualized because it is irrelevant for the purpose of this chart). It can be noticed that, for every point, all ellipses intersect one another; it follows that, within the uncertainty of the computed coordinates (around $3 \mathrm{~mm}$ ), there are not any differences in the position in each epoch.

In view of the fact that the coordinates seem to remain unchanged, we might consider computing a joint adjustment that we will call "July's mean state" including the measurements from the three epochs. The figure shows this result by an " $X$ " (coordinates) and an ellipse in tick black line. Since it is the average of a larger 


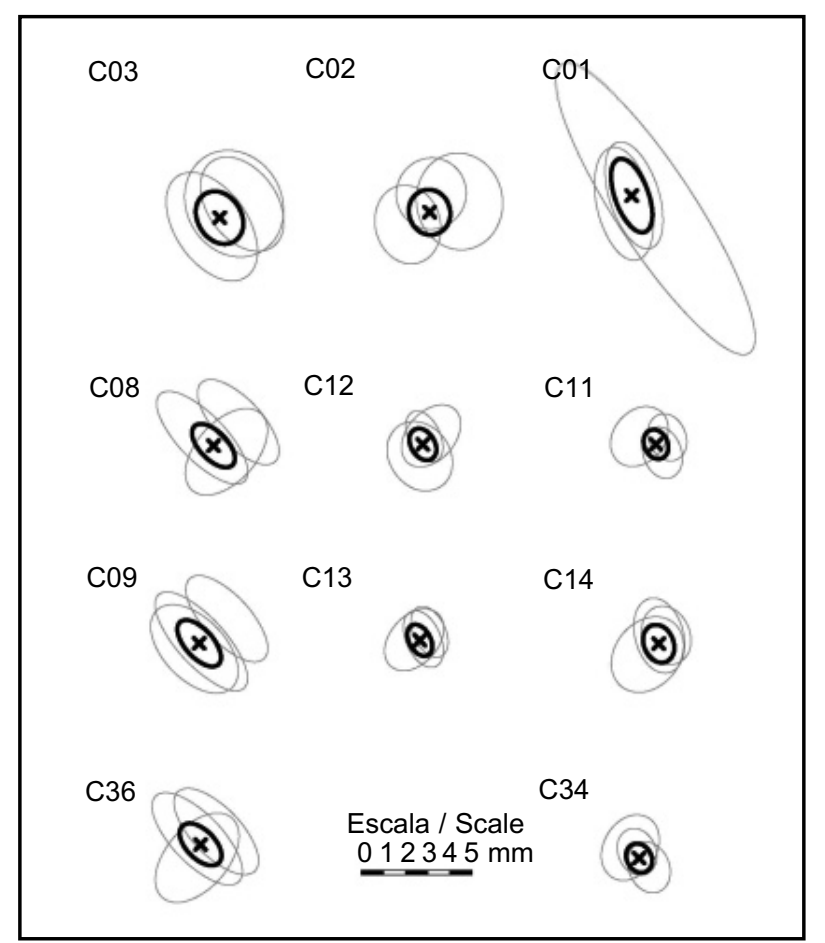

Figura 2. Elipses correspondientes a las tres campañas de julio (2007, 2008 y 2009) en gris claro y elipse resultante del ajuste conjunto de las tres campañas (línea gruesa negra) cuyo centro se marca mediante un aspa que se considera la situación promedia del estado "Julio".

Figure 2. In light grey : error ellipses corresponding to the three July's epochs : 2007, 2008 and 2009. Black line: resulting ellipses after computing the three epochs together, center points are marked with an " $X$ " and they are considered the July's mean position.

color negro que, como puede apreciarse, tiene un tamaño aproximadamente la mitad que el de cada campaña individual, ya que corresponde a un promedio de un mayor número de medidas.

Sin embargo, antes de aceptar la existencia de este estado promedio para el mes de julio, es necesario hacer una doble consideración:

- Desde el punto de vista matemático: se deberá comprobar que el ajuste conjunto es conforme al control estadístico antes comentado (tercera fase del proceso de cálculo), es decir, que al procesar de forma conjunta las medidas de diferentes campañas no aparecen incoherencias en el proceso de cálculo.

- Desde el punto de vista físico: si se considera que el edificio es una estructura dinámica sujeta a las condiciones atmosféricas (temperatura, presión, etc.), la posición real de los puntos en las diferentes campañas no será exactamente la misma, ya que estos factores tampoco lo son. La diferencia debe ser menor que la precisión de las coordenadas calculadas porque de lo contrario no pasará el control estadístico desde el punto de vista matemático, pero, en el caso de aceptarlo, vemos que el significado de las elipses number of measurements, this new ellipse has approximately half the size of any single one.

Nevertheless, before accepting the existence of this July's mean state, it is necessary to make a double consideration:

- From a mathematical point of view, we must verify that the joint adjustment pass the statistical checking (third stage in the computation process), in other words, when the measurements are put all together there is not any incoherency in the computation process.

- From a physical point of view, the building is a dynamic structure that is affected by atmospheric changes (temperature, pressure, etc.). The real position of the points at each epoch will not be exactly the same since these factors are also different. The difference will be smaller than the precision of the calculated coordinates, otherwise, the computation will not pass the statistical check mentioned in the mathematical point of view. However, if we accept it, we see that the meaning of 
se modifica. En efecto, en las campañas individuales, las elipses representan la incertidumbre de la posición real en un momento determinado debida a la precisión de las medidas; sin embargo, en el cálculo conjunto, las elipses incluyen además la zona en la que se mueve la posición real en función de las condiciones atmosféricas dentro del mismo estado "julio".

La Figura 3 añade a la información de la figura anterior las elipses de las campañas de enero de 2008 y enero de 2009 en gris con línea discontinua. Analizando en primer lugar las cinco elipses individuales, se aprecia que en algunos puntos hay parejas de elipses que aparecen claramente separadas lo que indica que las posiciones de los puntos en las campañas a las que hacen referencia no son coincidentes. Ahora bien, si se observan sólo las dos nuevas series de elipses, se vuelve a comprobar que se intersecan en todos los puntos, lo que nos puede llevar a actuar de forma similar a las campañas de julio y calcular un estado "promedio de enero" incluyendo de forma conjunta las medidas de enero de 2008 y enero de 2009. En la figura se muestra este resultado como elipses con línea gruesa de color negro representando las coordenadas promedio mediante una cruz.

Por lo tanto, en la Figura 3, las elipses en color negro marcarían la diferencia entre el "estado promedio enero" y el "estado promedio julio", es decir, los extremos del the ellipses changes. Indeed, for one epoch ellipses represent the uncertainty in the real position at a certain moment due to the accuracy of the measurements. Nevertheless, in the joint computation, ellipses also include the area in which the real position moves according to the atmospheric conditions for a same state "July".

The Figure 3 adds to the information of the previous one the ellipses of the January's 2008 and 2009 epochs in grey color and dashed line, as the individual July's epochs for the different years. Analyzing firstly these five individual ellipses, we can see that, for some points, there are couples of ellipses that appear clearly separated which means that the positions they are referring to do not match up. On the other hand, if we observe only the two ellipses for January we check that they intersect in every point, which can drive us to act similarly to the July's case and compute a mean state for January by putting together all observations of 2008 and 2009. This "January's mean state" is drawn with tick black ellipses and the coordinates are represented with a cross "+".

Therefore, in Figure 3, black ellipses represent the difference between the "January's mean state" and the "July's mean state", that is to say, the extreme locations

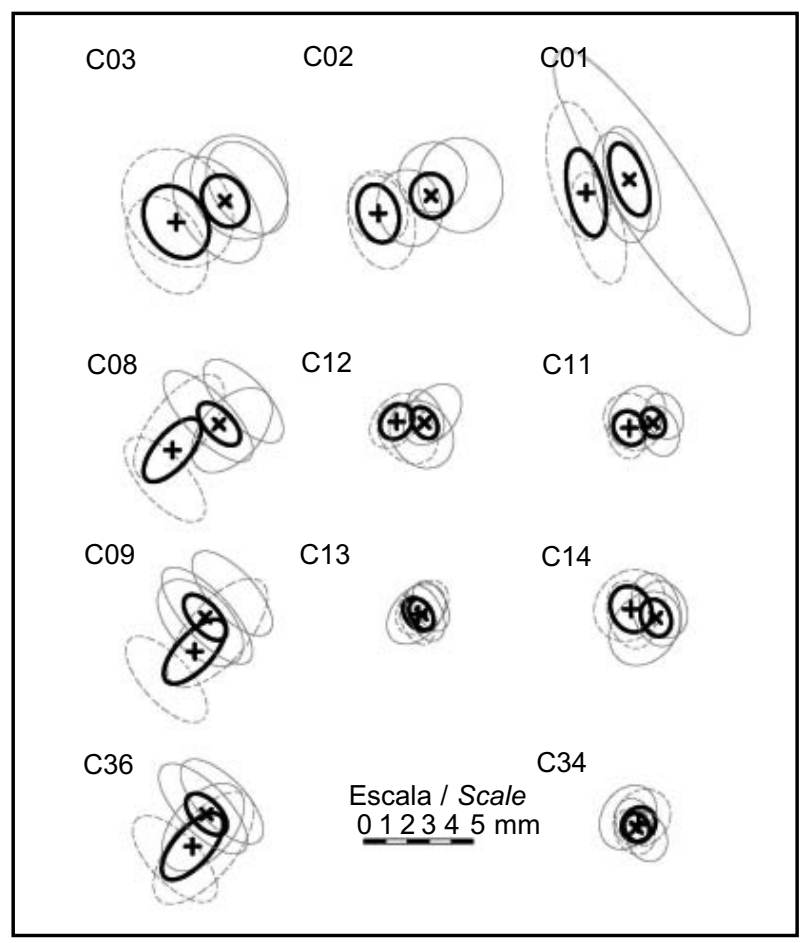

Figura 3. Sobre la información de la figura anterior, se han incorporado dos nuevas elipses correspondientes a las campañas de enero (2008 y 2009) con línea discontinua en gris claro y la resultante del ajuste conjunto representado con una línea gruesa negra con el centro marcado con una cruz.

Figure 3. Added to the data of figure 3, the graphic shows the two January's epochs (2008 and 2009) in discontinuous grey and their mean value as a thick black line with its center marked with a cross " + ". 
ciclo estacional. Se comprueba que este efecto aparece en las dianas de la línea superior (las correspondientes al campanario) y, en menor medida, en las de la parte alta del cuerpo de la torre (la diana C08 aparece separada, C11 y C12 se intersecan), siendo la posición de las dos filas inferiores equivalente en ambos momentos.

Respecto a los valores numéricos, indicar que, con los datos disponibles, sólo aparecen elipses diferenciadas cuando la variación es mayor de $2 \mathrm{~mm}$; concretamente la distancia para las dianas del nivel superior son: 2,1 $\mathrm{mm}$ para $\mathrm{C} 01 ; 2,6 \mathrm{~mm}$ para $\mathrm{CO2}$ y $2,4 \mathrm{~mm}$ para $\mathrm{C} 03$. Si trazamos una línea que una los centros correspondientes a "enero" y "julio", las medidas de los segmentos que quedan entre las elipses son $0,5 \mathrm{~mm} ; 0,7 \mathrm{~mm}$ y 0,1 $\mathrm{mm}$, respectivamente. Estos datos permiten apreciar la relación existente entre la separación de las coordenadas calculadas y la discriminación de las elipses de error.

Recapitulando la información que se puede extraer de la Figura 3, diríamos que no existen desplazamientos significativos entre las coordenadas medidas para el mismo momento del año en años diferentes, pero que la posición de algunos puntos varía entre los dos momentos determinados como "julio" y "enero", lo que puede explicarse debido a una variación estacional.

El análisis posterior de los datos consiste en interpretar estos desplazamientos individuales como parte del comportamiento global del edificio en 3D. Normalmente, esta interpretación se hará incorporando a los datos geométricos otras fuentes de información (datos meteorológicos, características de los materiales...).

No obstante, dado que no existe información adicional ni se dispone de un conocimiento previo sobre el posible comportamiento del edificio, podría ser interesante realizar una primera interpretación global desde una perspectiva puramente geométrica que, aunque incompleta, sirva como hipótesis de partida para futuros análisis.

El patrón de los desplazamientos parece sugerir que éstos son similares para los puntos situados a la misma altura (dirección y magnitud) y que además se incrementa la separación según se va ascendiendo.

Para ilustrar esta idea se ha preparado la Figura 4 en la que los puntos correspondientes a la posición de julio se presentan en tres líneas verticales, siendo la separación a lo largo de esta línea proporcional a la diferencia de altura real en el terreno. La escala correspondiente a la representación de las elipses (eje de abscisas) es 1.000 veces mayor que el del eje de ordenadas. Se dibujan las líneas inclinadas que unen las posiciones de la base de la of the seasonal cycle. This effect is shown in the highest targets (the ones on the belfry), it is less patent at the top of the body of the tower (target C08 appears separated while C11 and C12 intersect), and for the two lowest rows there are no differences between seasons.

As for the numerical values, in our case study ellipses are only separated when the variation is bigger than $2 \mathrm{~mm}$. More precisely, the distances for the targets of the highest row are: $2.1 \mathrm{~mm}$ for C01, $2.6 \mathrm{~mm}$ for $\mathrm{CO} 2$ and $2.4 \mathrm{~mm}$ for C03. If we draw a line connecting the positions in "January" and "July", the segments outside the ellipses measure $0.5 \mathrm{~mm}, 0.7 \mathrm{~mm}$ and $0.1 \mathrm{~mm}$ respectively. These data allow us to notice the relationship between separation of the position and discrimination ability of the error ellipses.

Summarizing what Figure 3 shows, there are not meaningful differences between the coordinates for any point if we measure them at the same moment of the year in different years but there are some points where the position is different at the state called "July" and at the one called "January", which can be explained by a seasonal variation.

Further analyses will consist of interpreting these individual displacements as due to a global behavior of the building in 3D. Usually, this interpretation will need to add information from other sources (meteorological data, characteristics of the materials, etc.).

Nevertheless, as there is not either additional information or a previous knowledge about the behavior of the building, it could be interesting to have a first interpretation from a point of view simply geometrical which, although incomplete, might be useful as a preliminary hypothesis for future analyses.

The pattern of movements suggests that they are similar for all points located at the same height (direction and magnitude) and they increase upwards.

In order to illustrate this idea, in the Figure 4 the points corresponding to July's position are presented in three vertical lines distributed proportionally to the real height. Vertical scale is 1000 times the scale of the ellipses (horizontal). We draw inclined lines connecting the point at the base (supposed unchanged in both seasons) to the January's positions on the belfry. We can see that the lines fit the position of the intermediate ellipses and 


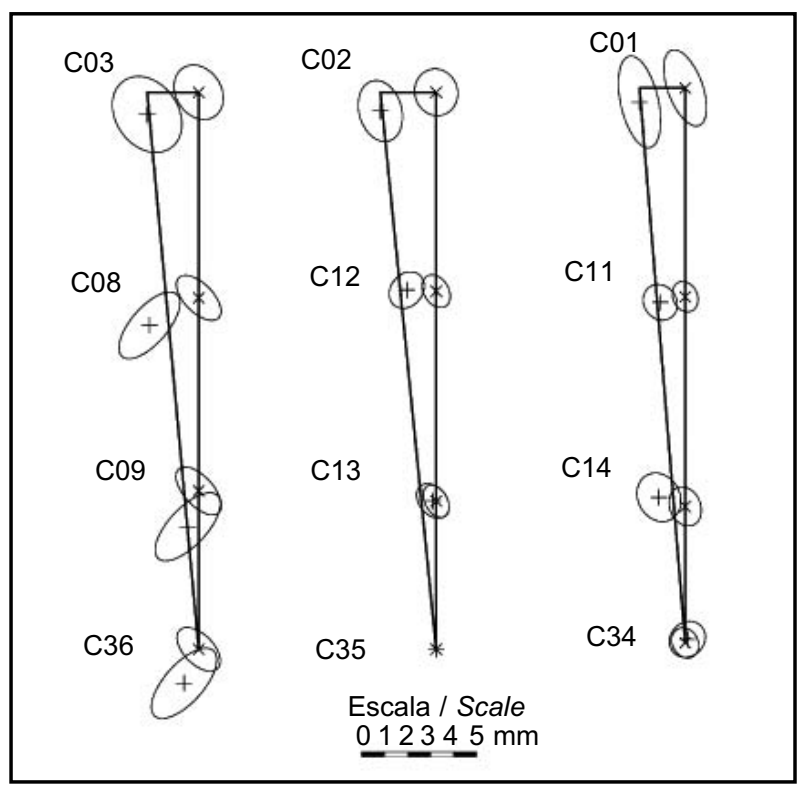

Figura 4. Ejemplo de posible interpretación de los resultados como un aumento de la inclinación de la torre de unos 19" (segundos sexagesimales). La relación entre la escala vertical y la horizontal en el gráfico es de 1000:1.

Figure 4. A possible interpretation of the results: increase of around 19" (sexagesimal seconds) of the leaning of the tower. In this chart, the ratio between vertical and horizontal scale is 1000:1.

torre (supuestas coincidentes) con las del campanario. Se puede apreciar que este gráfico se adapta a la posición de las elipses de las filas intermedias y que además el ángulo de inclinación presenta valores similares en las tres columnas: 19", 20" y 17" (segundos sexagesimales).

Por lo tanto, una posibilidad que explicaría los desplazamientos registrados sería la existencia de una variación en la inclinación de la torre cuyo valor se obtiene del promedio de las líneas inclinadas que aparecen en la Figura 4 y que es de unos 19".

Esta variación en la inclinación de la torre es una primera hipótesis de la dinámica de esta parte del edificio y, como tal, un punto de partida en el caso de que se decida acometer estudios de detalle, ya que permite prever qué tipo de movimientos se deben buscar y su magnitud (por lo tanto, se puede seleccionar el sensor más adecuado para registrarlos, así como los lugares dónde deben situarse).

Según se ha advertido repetidamente, es necesario vigilar que los cálculos no aparezcan distorsionados por medidas erróneas o deficiencias en el modelo matemático. El control sobre las medidas depende de la redundancia del sistema de ecuaciones, es decir, del número de medidas adicionales de que se dispone sobre las mínimas necesarias para el cálculo. En la práctica, las redundancias no suelen ser muy elevadas debido a la imposibilidad de observar las señales desde muchas estaciones o con buena geometría en todos los casos, por lo que their leaning is similar in every case: 19", 20" and 17" (sexagesimal seconds).

Hence, one possibility that can explain the registered displacements would be the existence of a variation in the leaning of the tower; the average of the three values gives an estimation of the value: 19" as shown in Figure 4.

So, we already have a first hypothesis about the dynamic of this part of the building and, as such, a start point in case it is decided to make a more detailed research because it allows to foresee which type of movements might appear and their expected values (thus, we can choose the most suitable device to record them and also know where the optimal locations for these devices are).

As it has been pointed out above, it is necessary to ascertain that the computations are not distorted by erroneous observations or deficiencies in the mathematical model. The control of the measurements depends on the system of equations and its redundancy, that is to say, on the number of additional measurements above the minimum necessary for the computation. In practice, redundancies tend to be poor due to the impossibility of observing the targets from many stations or under a good geometry for every case. For this reason and in spite of all 
siempre debe tenerse en cuenta la posibilidad de que, aún con todos los controles realizados, existan errores no detectados dentro del sistema. Debido a esto, es importante que las diferencias finales no aparezcan de forma individual, sino que puedan interpretarse de forma global, es decir, que los desplazamientos detectados en un punto vengan refrendados por los de sus vecinos.

\section{CONCLUSIONES}

A la vista de los resultados anteriores, se pueden extraer algunas conclusiones de carácter general.

En primer lugar, destacar la diferencia entre medidas e interpretaciones: lo que se mide es la posición de los puntos en diferentes momentos, posteriormente, estos datos se interpretarán como una variación de dimensiones, desplazamientos, velocidades, etc. Las medidas son datos objetivos, las interpretaciones dependen de consideraciones e hipótesis que las condicionan. Avanzar en las interpretaciones también significa alejarse de los datos originales.

Ahondando en esta diferencia, se podría decir que las interpretaciones intentan explicar las causas, mientras que las medidas reflejan su efecto, es decir, las consecuencias. Por lo general, los trabajos de auscultación geométrica se limitarán a la obtención de medidas, dejando las interpretaciones para fases posteriores en los que se analizarán conjuntamente con otras fuentes de información (estado de los materiales, sondeos, cargas, temperaturas...).

Las medidas topográficas aportan información en el espacio bidimensional o tridimensional, a diferencia de otros tipos de sensores (extensómetros, fisurómetros...) que proporcionan valores unidimensionales. Por este motivo, no existe una limitación en cuanto a disponer sólo de valores en la dirección de medida de los sensores, sino que se puede estudiar la variación entre parejas o grupos de puntos con independencia de la distancia que los separe o de que exista visibilidad o conexión física directa entre ellos.

La precisión de las coordenadas (elipses con semiejes de 2 y $3 \mathrm{~mm}$ ) es uno de los aspectos más importantes, ya que determina la magnitud de los efectos que se pretenden detectar.

Cabe destacar que las medidas topográficas son lentas de ejecución (se tarda toda una jornada en realizar cada campaña). No obstante, también hay que reseñar que existe equipamiento que permite la captura automática de datos (estación total robotizada y señalización específica que es reconocida automáticamente), lo que agiliza the checkpoints, the existence of undetected errors inside the system has to be always considered. Therefore, it is important that the differences do not appear as individualities but that they can be backed up by a global pattern, or, in other words, that the detected displacements in one point are confirmed by the displacement of the surrounding targets.

\section{CONCLUSIONS}

The results reported above lead to the following general conclusions.

First of all, the difference between measurements and interpretations should be stated clearly: what is measured is the position of the points at each moment (epoch), later, these data are interpreted as variations in size, displacements, velocities, etc. Measurements constitute objective data, whereas interpretations depend on considerations and hypotheses that condition them. Going ahead in the interpretation also implies to depart from the original data.

In order to further insists on this difference, it can be held that the interpretations try to explain the reasons, while the measurements reflect their effect, that is, the consequences. In general, geometrical monitoring projects will be limited to the acquisition of the measurements, leaving aside the interpretation for a later stage in which these measurements will be analyzed together with other sources of information (state of the materials, bore-holes, loads, temperatures, etc.).

Some devices (extensometers, crack meters, etc.) are one-dimensional, thus providing values only along the direction of the gauge. On the other hand, surveying measurements provide information in the two-dimensional or the three-dimensional space, irrespectively of which pair or group of points can be related whatever the distance and the fact that there is direct visibility or link between them.

The accuracy of the coordinates (ellipses with semiaxes of 2-3 mm) is one of the key aspects since it determines the magnitude of the effects that can be detected.

It is worth mentioning that surveying measurements is slow (the fieldwork of an epoch takes a whole day to be fulfilled). Nevertheless, state of the art equipments (robotized total station and specific targeting that is automatically recognized by the station) are able to register the information faster, although they increase 
la toma de datos, si bien supone un incremento en el coste. Los tiempos de observación son importantes, ya que las variaciones que sufren los puntos durante el tiempo en que se realizan las medidas se incorporan a la incertidumbre en sus coordenadas.

No se trata de un sistema de monitorización continuo (aunque el sistema robotizado antes aludido permite una frecuencia mayor de observaciones), por lo que no se debe considerar si se necesita un aviso inmediato en caso de colapso inminente.

Evidentemente, para determinar ciclos es necesario observar durante varios periodos completos; en el caso de las variaciones estacionales verano-invierno que estamos tratando, esto supone varios años.

Otro aspecto importante en los estudios a largo plazo es el mantenimiento de los sensores; en este caso se están utilizando señales pasivas (dianas de puntería) que han sido diseñadas, construidas e implantadas con materiales duraderos con el fin de que se puedan seguir siendo utilizadas durante muchos años.

Respecto al ejemplo concreto de la torre de Agoncillo, uno de los puntos más delicados es la asunción de los estados promedios "julio" y "enero" que se presentan en la Figura 3 y sobre los que se observa el ciclo estacional. Se ha justificado este paso en función de los datos de los que se dispone, pero no debe darse por sentado que vaya a ser posible realizarlo en cualquier otro proyecto por lo que siempre será necesario realizar un cuidadoso análisis de las campañas antes de realizar cálculos conjuntos.

De todas formas, la interpretación del ciclo no debe realizarse exclusivamente sobre las elipses promedios, sino que también deben tenerse en cuenta las individuales de cada campaña a partir de las cuales se han obtenido; por este motivo se presenta toda esta información en la Figura 3.

En resumen, en el presente artículo se representa parte del desplazamiento sufrido por la torre de la Iglesia de Santa María la Blanca de Agoncillo como consecuencia del ciclo estacional verano-invierno. La parte detectada, que corresponde a la componente horizontal, se ha registrado mediante medidas topográficas convencionales cuya precisión es de unos pocos milímetros $(2-3 \mathrm{~mm})$. Se detalla la metodología de cálculo empleada para obtener la solución y con qué garantía se pueden dar los resultados.

La utilidad de estos datos reside en las conclusiones posteriores respecto a la estabilidad del edificio o las características de los materiales que se puedan derivar, para the costs. Observation span is important because the variation inside this span is incorporated to the uncertainty of the coordinates.

Surveying can hardly be considered a system for continuous monitoring (although the abovementioned robotized equipment allows a higher frequency in the observations), then it is not advisable when there is a risk of immediate collapse and it is needed a quick warning.

On the other hand, we need several periods to record a cycle, which means several years of observations in the case of seasonal changes summer-winter.

Another important aspect in long-term studies is the upkeep of the sensors. In this project, we are using passive signals (targets) which have been designed, made and embedded with durable materials in the expectation that they will remain in good condition for a long time.

With regard to the case of Agoncillo, one of the most delicate points is the assumption of the existence of two average states for "July" and "January", which are presented in Figure 3 and over which the seasonal behavior can be observed. This step has been justified according to the data at our disposal but it is not always either straightforward or possible whatever the circumstances are. Consequently, epochs should be carefully analyzed before attempting to compute them together.

Anyway, as the original data are the individual epochs, we must not leave aside them completely and try to interpret the seasonal cycle from the average ellipses exclusively. For this reason, all this information appears in Figure 3.

Summing up, this paper reports the identification of part of the displacements undergone by an historical building (the tower of the church of Santa María la Blanca in Agoncillo) as a consequence of the seasonal cycle (summer-winter). The measured part is the horizontal component of the displacement. Measurements have been taken by surveying techniques and the accuracy of the results is a few millimeters $(2-3 \mathrm{~mm})$. The text details the computations of the results and their uncertainty.

The utility of these data lies in further conclusions that can be derived concerning the stability of the building or the characteristics of the materials. For this purpose, it 
lo cual será necesario ponerlos en relación con otras fuentes de información e hipótesis de trabajo.

\section{AGRADECIMIENTOS}

Queremos agradecer al Ayuntamiento de Agoncillo y a la Consejería de Cultura del Gobierno de La Rioja por la financiación del proyecto y a los vecinos de la localidad por las facilidades dadas durante los trabajos de campo. will be necessary to relate them to other sources of information and working hypotheses.

\section{ACKNOWLEDGEMENTS}

We would like to thank the Council of Agoncillo and the Culture Department of the Government of La Rioja for the funding of this project and our gratitude to the inhabitants of the town for their help during the fieldwork.

\section{BIBLIOGRAFÍA / BIBLIOGRAPHY}

(1) Valle Melón, J. M.; Rodríguez Miranda, Á.; Pérez Vidiella, P. (2008). Evaluation of the conventional surveying equipment applied to deformation analysis of heritage buildings. A case study: the bell tower or Santa María la Blanca church in Agoncillo (La Rioja, Spain), en Measuring the changes, $13^{\text {th }}$ FIG International Symposium on Deformation Measurements and Analysis and $4^{\text {th }}$ IAG Symposium on Geodesy for Geotechnical and Structural Engineering, 12-15 de mayo de 2008, Lisboa (Portugal), 11 pp., http://www.fig.net/commission6/lisbon_2008/papers/pas12/pas12_02_vallemelon_mc045.pdf], acceso en julio de 2009.

(2) Caspary, W. F. (1986). Concepts of Network and Deformation Analysis, University of New South Wales, Kensington (Australia), Monograph 11, ISBN 0-85839-044-2, 183 pp.

(3) Chueca Pazos, M.; Herráez Boquera, J.; Berné Valero, J. L. (1996). Redes topográficas y locales. Microgeodesia, Ed. Paraninfo, Madrid (España), ISBN 84-283-2310-0. 448 pp.

(4) Chueca Pazos, M.; Herráez Boquera, J.; Berné Valero, J. L. (1995). Ampliación de redes topográficas y locales. Cuestiones de diseño, Servicio de Publicaciones de la Universidad Politécnica de Valencia (España), SUPV-95274, 243 pp. 